\title{
DOOYEWEERD ON LAW AND MORALITY: LEGAL ETHICS - A TEST CASE
}

\author{
Alan Cameron*
}

The philosophical work of the Dutch Christian inteliectual Herman Dooyeweerd is not internationally well known. His major jurisprudential work is even less well known owing to the fact that it has not been published either in his native language or in English. The author of this article, who is involved in the editing of the Englisin translation of Dooyeweerd's jurisprudence for publication, briefly expounds the main themes and some of the basic concepts of his legal philosophy with reference to the general probiem of the relationship between law and morality and then attempts to apply these insights towards a theoretical elucidation of the relationship between law and legal ethics. Central to the Dooyeweerdian jurisprudential perspective is a highly original theory of the modal aspects. In particular, the notions of the jural and ethical aspects provide the basis of his unique account of the reiationsitip between law and morality and of this article's application of Dooyeweeerd's theoretical framework to the topic of legal ethics.

\section{INTRODUCTION}

The problem of the nature and source of law's normativity is a major preoccupation of legal philosophy. H L A Hart's The Concept of Law ${ }^{1}$ centred its criticism on the failure of Austinian legal positivism to adequately account for the obligatory character of legal rules. His notion of the "internal point of view" which plays a critical role in Hart's legal positivist concept of law as the union of primary and secondary rules directly addresses this aspect of legal normativity. Furthermore, his conception of legal validity based on the identification of formal conditions for the existence of valid law (rule of recognition) and the sharp distinction drawn between law and morality are regarded as basic features of this theory which set apart from against the traditions of natural law theory.

Senior Lecturer, School of Accounting and Commercial Law, Faculty of Commerce and Administration, Victoria University of Wellington.

1 H L A Hart The Concept of Law 2nd ed(Oxford University Press, Oxford, 1994). 
Since the appearance of The Concept of Law, beginning with Hart's own "minimum content of natural law", the dividing line between legal positivism and natural law on the question of the relationship between law and morality has become increasingly blurred. Neo-Hartians such as Neil MacCormick see a more-than-contingent connection between law and morality. ${ }^{2}$ And "soft positivists" even believe it possible to have moral elements as part of the criteria for valid law whilst still maintaining a positivist account of legal validity. ${ }^{3}$

From the other side of the natural law/legal positivist divide John Finnis has made us re-examine the view that natural law theories are founded on logical or other philosophical error. ${ }^{4}$ His revised Aristotelian-Thomist theory challenges legal positivism by defending a version of natural law theory which adopts the analytical tools of positivist legal philosophy and some of its concepts, ${ }^{5}$ including a view of legal validity compatible with legal positivism. ${ }^{6}$ To a "post-positivist" such as Neil MacCormick, therefore, Finnis's natural law holds some attractions. Neo-positivists have moved away from Hart's attempt at a "descriptive sociology of law" based on ordinary language analysis towards an account of law as a form of practical reasoning. MacCormick, as one of the leading figures in this movement, finds common ground in Finnis's interpretation of the normative (natural law basis) of positive law as the fulfillment of the requirements of practical reasonableness. ${ }^{8}$

Whilst the natural law/legal positivism divide may have become less certain, the debates over legal normativity itself have not been less vigorous. Whether or not Fuller's "inner morality of law" is correctly categorised as a natural law theory the issues involved in his sharp disagreement with Hart's positivism over the status of Nazi law are still of

2 See N MacCormick, "Natural Law and the Separation of Law and Morals" in R P George Natural Law Theory: Contemporary Essays (Oxford University Press, Oxford, 1992) 105-133.

3 Hart himself admitted to being a soft positivist. See above n 1, 250-251.

4 See Chapter 2, J Finnis Natural Law and Natural Rights (Oxford University Press, Oxford, 1980) 2355 , where he defends Thomistic natural law against the accusations of deriving natural law from human nature and "ought" from "is".

5 Consider, for example, the way in which he applies the analytical concepts of the "central case" and "focal meaning" to Hart's concept of the "internal point of view." Above n 4, 11-18.

6 Above n 4, 268-269.

7 See his comments in the foreword to second edition of N MacCormick Legal Reasoning and Legal Theory (Oxford University Press, Oxford, 1994) ix, xiv - xvi, where he describes how he has moved away from some aspects of Hartian theory into a "post-positivist" phase.

8 N MacCormick, however, maintains his positivist stance by rejecting Finnis's cognitivist "metatheoretical" stance that asserts the self-evidence of his basic goods as the foundation of his natural law theory of law. For MacCormick practical reasonableness is not itself one of the basic goods but their constructive source. See above $\mathrm{n} 2,128$. 
interest. ${ }^{9}$ More recently, Ronald Dworkin has launched a sweeping attack on Hartian legal positivism in which he rejects the positivist ("conventionalist") view of valid law as independent of morality and replaces it with an "interpretive" conception of law founded in the normative requirement of integrity. ${ }^{10}$

A very different approach to the central philosophical problem of law's normativity is to be found in the legal philosophy of the former professor of jurisprudence at the Free University of Amsterdam, Herman Dooyeweerd (1894-1977). The current occupant of that position, Professor Arend Soeteman, in providing an assessment of Dooyeweerd as a legal philosopher ${ }^{11}$ has identified key elements in Dooyeweerd's concept of law which are also found in three of the leading Anglo-American legal philosophers of recent times mentioned above - Hart, Dworkin and Finnis.

In this essay I attempt to demonstrate the originality of Dooyeweerd's account of the normative character of law with particular reference to his views on the relationship between law and morality by utilising his jurisprudential method and basic concepts towards providing a new perspective for understanding the relationship between law and legal ethics. The second part of the study following this introduction provides a necessarily brief exposition of the main elements of Dooyeweerd's theory of law and his account of the relationship between law and morality. The third and central part of the article applies Dooyeweerd's theoretical perspective on the relationship between law and morality and its key concepts explained in the preceding part to the topic of legal ethics. The final part offers some concluding observations on the significance of Dooyeweerd's legal philosophy and its implications for issues of law and morality in general.

\section{THE JURAL AND THE ETHICAL ASPECTS IN DOOYEWEERD'S LEGAL PHILOSOPHY}

\section{A Philosophy of the Cosmonomic Idea, Encyclopaedia of Legal Science and the Relationship of Law and Morality}

In a desire to give a more satisfactory explanation of the normative character of law in its factual experiential context than his contemporary legal philosophers were able to do, ${ }^{12}$ and based on a conviction that this could only be accomplished through constructing a

9 For example, see MacCormick's defence of Fuller against Hart, above n 2, 122.

10 R Dworkin Law's Empire (Fontana, London, 1986). This work incorporates earlier criticisms of Hartian positivism in Taking Rights Seriously (Duckworth, London, 1977).

11 A Soeteman "Dooyeweerd als rechtsfilosoof" in H Geerstema et al Herman Dooyeweerd $1894-1977$ (Kok, Kampen, 1994) 28-49.

12 R D Henderson Illuminating Law (Free University, Amsterdam, 1994) Ch 3, 51-87. 
philosophy rooted in a radically Christian life-and-world-view, ${ }^{13}$ Dooyeweerd produced his "Philosophy of the Cosmonomic Idea". This in turn resulted in his major jurisprudential work ${ }^{14}$ which embodied the central ideas and adopted the method of his main philosophical work. $^{15}$

His philosophical ontology is based on the original idea that experiential reality is governed by law-like ordering conditions independent of human subjectivity which human theoretical knowing is able to explicitly discern as ways in which that reality functions. These ways of law-governed functioning or "law-spheres" are modal aspects, not concrete "things," but universal, irreducible modes in which concrete things, entities, processes, relationships, etc function. ${ }^{16}$ These are the "presupposita" of concrete experience. Every theoretical attempt to account for that experience, necessarily presupposes a view of these aspects in their diversity, coherence and unity in a basic idea of "law-idea" or "groundidea" (their "presuppositions") under the "religious" directing of a basic ground-motive. ${ }^{17}$

The jural aspect is that mode of reality which imparts to law and concrete legal phenomena their distinctively legal or jural character. A theoretical explanation of law and legal phenomena, therefore presupposes a view of the jural aspect and its "meaning-kernel" or "nucleus" as a distinct aspect amongst other distinct irreducible modes in their diversity, interconnections (coherence) and unity. In an original manner Dooyeweerd characterises the meaning-nucleus or core of the jural aspect as a normative mode in the notion of "retribution" or as a retributive mode having a broad juridical meaning of legal justice. ${ }^{18}$

13 Henderson, above, n 12, 32, 50.

14 H Dooyeweerd Encyclopaedie der Rechtswetenschap (Studentenraad, Vrije Universiteit, Amsterdam, 1946-1967). It comprised several volumes of 'notes' prepared for his students which were never published despite Dooyeweerd's taking steps towards this end. An English translation of the set of student notes comprising the introduction to Encyclopaedie der Rechtswetenschap is in the process of being edited for publication. It will be volume I of the set, Encyclopedia of Legal Science in The Collected Works of Herman Dooyeweerd A-Series (A8) to be published by Edwin Mellen Press in collaboration with the Dooyeweerd Centre for Christian Philosophy.

15 H Dooyeweerd A New Critique of Theoretical Thought (Presbyterian and Reformed, Philadelphia, 1954-58).

16 For the theory of the modal aspects see Dooyeweerd (1954-58) above, n 15 vol II, 3-426. For an introduction to the theory see L Kalsbeek Contours of a Christian Philosophy (Wedge, Toronto, 1975) 91-113.

17 For the theory of the ground-ideas and religious ground-motives see Dooyeweerd (1954-58) above, n 15, vol I, "Prolegomena" 3-164.

18 See Dooyeweerd (1954-58) above, n 15, 129-140 and (1946-67) above n 14, vol II, 3-9 for a defence of his account of the core meaning of the jural aspect and his rejection of others' attempts to reduce it to the core meaning of non-jural aspects as leading to internal inconsistencies or "antinomies." For a recent assessment of Dooyeweerd's conception of retribution as the core 
This mode, however, is quite distinct from the ethical, or moral aspect, the meaning-core of which he described as love. ${ }^{19}$ Notwithstanding the distinct irreducibility of the diverse modal aspects (modal sphere-sovereignty") the coherence of the aspects is guaranteed by the internal complexity of these aspects which connect with one another through their "analogical" structure. An account of the jural aspect necessarily appeals to its constitutive analogical elements. ${ }^{20}$ However, its core meaning is not reducible to any one of them or even to all of them together for they presuppose and are qualified by the core retributive meaning of the jural aspect which is unable to be further analysed. ${ }^{21}$ Hence the notion of legal harmonising implies a direct appeal to the aesthetic aspect of experience in an analogical sense - analogical, because the meaning of legal harmonising has a jurally qualified retributive meaning, not the original meaning of aesthetic harmony as would characterise a work of art, for example. ${ }^{22}$

The key to understanding the relationship between law and morality lies in the moral analogy within the jural aspect. Because the normative moral aspect immediately succeeds the jural in the temporal order of the aspects, ${ }^{2.3}$ the moral ("anticipatory") analogy is not a constitutive element in the structure of the jural aspect. ${ }^{24}$ The concept of law as a theoretical

meaning of law and the jural aspect see Soeteman, above $n$ 11, 33-34.

19 Olthuis, adopting the Dooyeweerdian modal analysis, preferred the term "troth" or "fidelity" to avoid confusion of this distinct mode of human experience with the normatively allencompassing "religious" meaning of love. J Olthuis Facts, Values and Ethics (Van Gorcum, Assen, 1968) 198-199.

20 Dooyeweerd provides the following description of the "nucleus" of the jural aspect which refers explicitly or implicitly to the constitutive analogical elements: "an irreducible mode of balancing and harmonising individual and social interests. This mode implies a standard of proportionality regulating the legal interpretation of social facts and their factual social consequences in order to maintain the juridical balance by a just reaction, viz. the so-called legal consequences of the fact related to a juridical ground", Above n 15, vol II, 129.

21 See Dooyeweerd (1954-58) above n 15, vol II, 129. and (1946-67) above n 14, vol II, 3.

22 For Dooyeweerd's account of the irreducibility of each aspect and their interconnections (coherence) via their internal "analogical" structure see Dooyeweerd (1954-58) above n 15, vol II, 55-179.

23 Using the illustration of the purchase of a box of cigars Dooyeweerd refers explicitly to the following aspects of the event: in (temporal) order they are the numerical, spatial, physicochemical (physical) biotic faith, psychical or sensory, logical, historical, linguistic, social, economic, aesthetic, jural, ethical and faith (or "pistic") aspect. This amounts to 14 distinct aspects or modes in which concrete reality functions. In the most mature expression of his philosophy he separated out from the physical a further aspect of movement ("kinematic"). See above n, 14, vol I, 2-6.

24 In his mature philosophy analogies within an aspect are either "retrocipations" or "anticipations". Retrocipatory analogies refer back to aspects earlier in the temporal order and are constitutive of the aspect concerned. Anticipatory analogies point forward to later aspects and open up the aspect through human subjective functioning in the faith aspect. See Dooyeweerd (1954-58) 
account of the aspect which gives to concrete law its jural character expressed as a retributive mode of harmonising different legal interests does not include the actualisation of the moral dimension (analogy) as an essential component. ${ }^{25}$ It is only in the idea of justice as a legal ideal (idea of law) ${ }^{26}$ that the concept of law is "opened up" by the moral "anticipatory" analogy within the jural aspect under the leading of the aspect of faith. This is concretely illustrated by the role of the Christian faith within Western legal traditions in bringing this moral dimension into the law through the concepts of "equity", "conscience", "good faith", "guilt", etc. ${ }^{27}$ Whilst these "legal-moral" concepts have come to be regarded as essential elements of our idea of legal justice they are not essential for the existence of valid law in every legal system. ${ }^{28}$

Thus, it can be seen that by means of his "structural" modal theory Dooyeweerd is led to a view of the interrelationship of law and morality that is similar in important respects to that of modern legal positivism. ${ }^{29}$ First, his concept of law implies a notion of valid law that is independent of moral criteria; hence like the positivists he believes that the existence of law is one thing, its morality or justice is another. Secondly, like modern positivists such as MacCormick he is able to maintain the distinctiveness of law and morality without asserting their separation into hermetically sealed spheres, even though "morality" or the moral aspect, for Dooyeweerd, has a more restricted meaning than in current jurisprudential and ethical literature. ${ }^{30}$

It is not merely the making of a firm distinction between law and morality that characterises legal positivism; a jusnaturalist such as Finnis demonstrates that a theory of

above n 15, vol II, 164-180.

25 See Soeteman, above n 11, 30-36 for a comparative analysis of Dooyeweerd's concept of law.

26 See, Dooyeweerd (1946-67) above n 14, vol II, 30; H J van Eikema Hommes Major Trends in the History of Legal Philosophy (North Holland, Amsterdam, 1979) 374-387.

27 Dooyeweerd (1954-58) above n 15, vol II, 141. For the "opening-process" with reference to law see Dooyeweerd (1946-67) above n 14, vol I, 63.

28 For a discussion of Dooyeweerd' s concept of legal validity in the context of legal positivist and natural law views see Soeteman, above n 11, 36-40.

29 Although, as a general observation I agree with Soeteman in relation to this aspect of Dooyeweerd's legal philosophy, I would argue more strongly than he for the distinctiveness and originality of Dooyeweerd's views on legal validity and the relationship between law and morality. For example, I do not necessarily agree that Dooyeweerd would have had to seriously consider changing some of views in this regard had he available the insights of modern positivists (and natural law theorists such as Finnis). See above $n 23$.

30 The moral aspect is but one of a plurality of "normative" aspects beginning with the logical which also include the jural. See above $n n 19$ and 21 and accompanying text. 
natural law also recognises the distinction in the sense asserted by positivism. ${ }^{3 i}$ For Dooyeweerd it is the overriding importance given to the element of positivisation (historical form-giving) in its account of law as a "social" fact that characterises legal positivism. The difficulties which the latter has in accounting for the source of law's normative validity including any moral component, can be attributed to this "absolutising" of the aspect of legal form-giving. ${ }^{32}$ What positivism lacks from Dooyeweerd's perspective is any notion of "supra-arbitrary" (ie independent of human willing), non-posited, legal principles or norms which are founded in the normative jural aspect and are positivised in some fashion in concrete law. ${ }^{33}$ Furthermore, to the extent that modern natural law theory (ie Finnis) adopts legal positivism's concept of legal validity it suffers from the same just-mentioned defects of that concept.

It is only through the idea of the jural aspect and its accompanying relation between the "norm-side" or "law-side" and "subject-side" or "factual side" of the functioning of concrete legal phenomena in that aspect that it is possible to attain a clearer view of legal normativity and the relationship between law and morality. ${ }^{34}$ As part of the datum of our concrete legal experience, the non-positive material legal norms or principles, including the legal-moral principles (such as good faith in contracts) never exist in themselves in some normative realm of "things" ${ }^{35}$ but can only be accounted for as positivised principles and

31 See above nn $4-8$ and accompanying text.

32 For example, the well-known problem of circularity in Hart's rule of recognition as the secondary rule which contains the criteria of laws' validity. A positive rule whether a Hartian "social rule", a state law or the Hartian rule of recognition as a social fact on which all valid laws depend all presuppose (for Dooyeweerdians) the positivising of a non-factual, non-positive (supra-arbitrary) jural norm. MacCormick's attempt to overcome the problem of circularity in an historical explanation was by his own admission unsuccessful. See D N MacCormick "The Concept of Law and 'The Concept of Law'“ (1994) 14 Ox JLS 1, 14.

33 Soeteman, above n, 11, 36-41.

34 An account of this relation and other "categorial" relations (subject-object and coming into being termination) required for giving an account of complex legal phenomena is found in Dooyeweerd (1946-1967) vol II, 98-102, above n 14. For his utilisation of this relation (and subject-object relation) to explain the "basic elementary concept" of legal causality see "The Modal Structure of Jural Causality" in H Dooyeweerd, Essays in Legal Social and Politica! Philosophy (Mellen, Lewiston. 1997) $39,45-47$.

35 For a helpful discussion of Dooyeweerd's rejection of "thing"-based theories of law and its connection with theoretical accounts of legal norms see Soeteman, above n 11, 31-36. However, I do not necessarily agree with his interpretation of Dooyeweerd's account of legal norms as closer to contemporary "thing" approaches than Dooyeweerd himself suggests. On the contrary it could be suggested that a contemporary theoretical account of legal normativity such as MacCormick's notion of (normative) institutional facts is closer to Dooyeweerd's idea of norm- and subject-side of concrete legal facts. See D N MacCormick "Law as Institutional Fact" in MacCormick and Weinberger An Institutional Theory of Law (Reidel, Boston, 1986) 49. 
norms on the norm-side of concrete legal facts. A full account of legal norms and principles, nevertheless, also presupposes a theoretical account of the individuality of (normative) "things" (laws, legal entities, etc).

\section{B An Elaboration of the Modal Theory with reference to Law and Morality}

To appreciate the implications of Dooyeweerd's legal philosophy for issues of law and morality requires us to grasp the significance of the notion that the jural aspect along with all the other modal aspects is a universal mode of functioning.

Every kind of human community and relationship, from the most intimate (marriage, family, friendship) to the most all-encompassing (state) functions in the jural aspect along with every other aspect including the moral aspect. It follows that each kind of community has its own inner jural sphere of law. However, the typical manner in which that aspect expresses itself within the different kinds of human community, that is, the type of law that is found within each basic kind of community depends upon the typical character of the individuality-structure of the community or relationship. The family, no less than the state has its own type of law, but the typical features of each are profoundly different. The structure of the family is typified by the leading or qualifying function of the moral aspect of love binding this community. Though founded in the biotic aspect (sexual reproduction), the moral/ethical dimension typifies the internal relationships and is constitutive of this community. ${ }^{37}$ Its internal jural sphere therefore is morally qualified and the concrete expression (positivisation) of the jural principles within it constitutes a moral type of law that is only applicable within the confines of that community. The rules and understandings which operate within individual families for the resolving of internal conflicts of interests in order to retributively (justly) restore family harmony are governed by the typical moral character of this basic societal institution. Parents who lay down rules of behaviour for their children or for the entire family will typically express the love and concern they have for their offspring and the moral integrity of the family. The internal rules of an economic enterprise are also instances of genuine law but typically qualified by its leading economic mode of frugal administration of scarce resources. ${ }^{38}$

The internal spheres of (juridical) law of these "private" communities are quite different from the rules to which we commonly attribute the description "law" - the internal jural sphere of the state, categorised by lawyers and doctrinalists as public and private law. For Dooyeweerd, however, the internal rules of a family or voluntary association (club, trade

36 For Dooyeweerd's theory of individuality-structures see, above n 15, vol III, for example, 53-156 (natural things) 266-304 (family) 304-339 (marriage) and 379-508 (state).

37 Dooyeweerd (1954-58) above n 15, vol III, 270.

38 See Dooyeweerd (1954-58) above n 15, vol II, 66-68 for a fuller definition. 
union, etc) are no less law than state legislation. The differentiating feature of state law, ${ }^{39}$ however, is that it is itself jurally qualified because the jural aspect is the state's "qualifying" or "leading" function. ${ }^{40}$ The state is a public-legal institution founded in a monopoly of coercive sword-power but qualified by the norm of public justice. ${ }^{41}$ State law then is typified by its public legal character. This public legal character of state law possesses a dual character. As for every other human community the state has its own internal communal law (constitutional and administrative law) that constitutes its legal structure and the relationships between different parts of that structure including the relationships between organs of the state and those subject to its authority, its citizens. In addition, the state in its public legal function has the task, which it alone possesses, of integrating all other jural spheres of non-state communities and of "inter-individual" or "coordinational" relationships in a common private law, ${ }^{42}$ of which the Common Law is a particular historical form within common law jurisdictions.

This common, private (civil), state law carries out the function of binding the private jural spheres of coordinational relationships to public legal norms of public justice. Hence, in a legal system which, as a result of historical development, displays a differentiated and morally opened up form, the (common) law of contract binds the private economic institution of contract in the sphere of commerce to public legal norms of equity, and legal certainty (security of agreements), to norms of commercial legal justice. At the same time that common state law respects the original jural competence of the parties to positivise the internal jural norms of the relationship in the form of an agreement containing contractual obligations which are jurally binding inter partes. The (state) law of contract gives public legal recognition to the privately generated jural expression of the economic relationship through permitting such agreements to be enforced and by granting state enforceable remedies for its breach, subject to the agreement fulfilling the public legal requirements of formation of agreement. Or it may set aside otherwise binding agreements for violation of such moral legal duties of unconscionability, good faith, etc.

The implications of Dooyeweerd's account of the different types of law are profound. First his theory propounds a version of legal pluralism with a robust sociological basis. ${ }^{43}$

34 See above $n$ 15, vol III, 379-508 for Dooyeweerd's theory of the state and its internal jural sphere.

41) Above n 15, vol III, 433-436.

4 See Dooyeweerd (1954-58) above n 15, vol III, 433-446, and (1996) above n 32, 148-150

42 Dooyeweerd (1954-58) above n 15, vol III, 438-450 and (1996) above $n$ 32, 64, n 1 and accompanying text.

$\$ 3$ See Dooyeweerd (1996) above n 14,73-89. I would suggest Dooyeweerd's theorv provides a rigorous theoretical basis for legal pluralism which Tamanaha considers to be missing from the current movement of legal pluralism See B Z Tamanaha "The Folly of the 'Social Scientific' 
One is apt to overlook this feature of his legal philosophy when focussing solely upon his account of the basic concepts of law; most of his examples in the Encyclopaedie, not surprisingly, refer to state law as the most important form of law, societally speaking. However, Dooyeweerd's concept (and idea) of law in principle applies to every type of law. Hence the constitutive principles corresponding to the "retrocipatory analogies" within the jural aspect apply to every type of law or jural sphere as well as to state law.

This theory, then, is anti-positivistic, not only in respect of the older law-as-command variety of legal positivism found in Hobbes, Austin and Bentham, but also with regard to the modern interpretations of legal positivism. The latter, although rejecting the command theories, still focus their attention on state law as the "central case" of law. Hart's concept of law as a system of secondary and primary rules is appropriate to describe the public legal rules of the state. But for Dooyeweerd a "social rule" is as much law whether in a prestate society or in a modern society. The rules of etiquette as much as the provisions of the New Zealand Bill of Rights Act 1990 are law in the fullest sense of law. The greater weight or social importance attributable to the latter is on account of the type of law that it is, not for being any less a law in its "focal" sense. On this theory of legal classification, not only the modern legal positivists, however, are guilty of state law bias. Even avowed antipositivists such as Fuller and Dworkin fall into this trap. For example, whilst Fuller appropriately acknowledged the inner normative constituents of valid law some of his eight "desiderata" ${ }^{\prime 4}$ are only applicable to the type state law with its public legal qualification. In its coordinating or integrating task the requirement of promulgation, for example, is especially appropriate to the public function of state law. The requirement of congruence between the law as announced and official action clearly only has the rules of state in mind. His definition of the purpose of law as "the enterprise of subjecting human conduct to the governance of rules" ${ }^{\prime \prime 5}$ contains a state bias in the concept of governance. Dworkin's state law bias is even more explicit in his "interpretive" abstract "concept" of law as a scheme of rights and responsibilities flowing from past political decisions about when collective force is justified.$^{46}$ on the basis of which he provides his "conception" of law as integrity.

Dooyeweerd's legal pluralism theory has profound implications for the issues of law and morality. It permits us to see more clearly the practical significance of his modal theory and the idea of the jural and moral dimensions as distinct modal aspects. The implications of

Concept of Pluralism" (1993) 20 JL \& Soc 192.

44 L Fuller The Morality of Law (Rev Ed, Yale, New Haven, 1969) 33-94 and the summary of eight "moral" requirements and discussion in J D van der Vvyer "Law and Morality" in Fiat Iustitia E Kahn (ed) (Juta, Cape Town, 1983) 350, 358.

45 Fuller, above n 44, 106.

46 Dworkin above n 10, 93. 
this approach for an understanding of the relationship between law and morality will be illustrated in the following section by providing an admittedly sketchy indication of how it can be applied to the topic of legal ethics.

\section{LAW AND LEGAL ETHICS}

From the perspective of Dooyeweerd's legal philosophy it is important for a proper understanding of the relationship of law and morality to make a clear distinction between "legal morality", and legal ethics. ${ }^{47}$

\section{A Legal Morality}

By legal morality we understand legal principles or duties which have a moral content, expressed in general terms by Dooyeweerd as the concept of law morally "opened up" by the idea of law or justice. We are speaking here of such legal-moral concepts as good faith, unconscionability, guilt, etc which have a distinctively jural meaning qualified by the retributive mode of harmonising jural interests (legal justice). ${ }^{48}$

In its jural sense good faith requires disclosure of information the withholding of which would be harmful to the interests of the other party whether this be within an economically qualified relationship (commercial contract) or a morally qualified relationship (friendship). The consequences of failure to observe moral norms such as good faith within the context of economic relationships (commercial transaction or consumer sale) where it is damaging to the economic interests of the other party may be provided for within the private jural sphere of the relationship (the contract) by the parties themselves. For example, an insurer will provide for the consequences of breaches of the duty of utmost good faith (material nondisclosures, misstatements, false statements) by the proponent in the proposal or insured in making a claim. However, the importance of commercial morality for the security and stability of commercial and consumer transactions requires the state to bind those inner

47 Although Professor van der Vvyer is an adherent of the Dooyeweerdian analysis of types of law with its regulative idea of law or justice that opens up these different types of law in an ethical fashion, he does not clearly explain the relationship between positive state law with its legalmoral concepts as a public-legal type of law and the internal "law" of legal professional relations with its own legal-moral component. As explained in the text below the internal regulations of the profession comprise a fiduciary- ethical type of law within the sphere of professional legal conduct or "legal ethics." Van der Vvyer's use of "legal ethics" to refer to legal-moral concepts in general within the different types of internal legal spheres (e g, in the title of J D van der Vvyer "The Jural Credo" (1989) 52 THRHR, 157) in this respect is confusing. Van der Vvyer himself, citing du Plessis, refers to the inappropriateness of denoting the "juridical facet" of the rules of professional conduct as "professional ethics." The same however could be said of his own use of "legal ethics" to denote the legal-moral component of that "juridical facet" of professional legal ethics. See van der Vvyer (1983) above n 44, 176 and (1989) above 354.

See discussion of the "nucleus" or "meaning-kernel" of the jural aspect, above $\mathrm{n} 20$ and text. 
jural spheres (contracts) into a compulsory common regime of moral-legal norms consistent with a general conception of public legal justice. To continue our insurance example, the state supports the concept of a general duty of (utmost) good faith (uberrima fides) in all contracts of insurance via a general common law duty. ${ }^{49}$ It also requires that insurers not use their superior bargaining position to depart from a conception of public justice that imposes the good faith duty by onerously extending it in their favour to the disadvantage of the insured. When, for example, insurers require the proponent of insurance to warrant the accuracy of all statements made in the proposal, the state insists that only misstatements which meet the common law standard of "materiality" under the duty of utmost good faith will allow the insurer to avoid the contract. ${ }^{50}$

\section{B Legal Ethics}

\section{Fiduciary relationships and ethics}

Not only economic relations possess an inner jural dimension which is bound as a matter of the public interest to state legal norms of justice. It is considered to be excessively intrusive to informal relations of friendship and lacking in any overriding public interest justification to make the parties within such relationships comply with a state law enforcing the inner jural norms of good faith even where failure to observe the latter results in damage to such relationships. There are other kinds of relationships, however, where the law is prepared as a matter of the public interest to regulate by imposing legal-moral duties. These kinds of relationships include those into which lawyers enter when practising their profession. The positive norms established by the profession itself for conduct within these relationships are what is commonly referred to as legal ethics.

The doctor when practising within the "caring" profession through utilising his or her expertise to maintain and promote the bodily well-being of the patient is regarded as having entered into a relationship with the patient which carries with it ethical duties (medical ethics). Similarly, the lawyer in exercising his or her professional skill by providing legal services (legal advice, preparing legal documents, acting for the client in legal proceedings, etc) is regarded as having entered into a relationship accompanied by ethical obligations (legal ethics) vital to the maintenance of the relationship. Whilst not all ethical obligations within professional relationships are legally enforced in what I have referred to as legalmoral duties, those that are so enforced are termed "fiduciary duties" and the relationships within which they arise, fiduciary relationships. ${ }^{51}$ Owing to the ethical nature of the

49 The duty is codified in the case of marine insurance. See Marine Insurance Act 1908, ss 18(1) and 20(1).

51) See ss 4- 6 lnsurance Law Reform Act 1977.

51 A leading text on the law of fiduciaries is P D Finn Fiduciary Obligations (The Law Book Co, 
obligations attaching to these relationships, when we employ the Dooyeweerdian analysis it appears natural to ascribe to the moral aspect of these professional relationships the qualifying or leading role within their internal structure. Indeed, this is precisely how I first viewed the matter. After all, the obligations central to the law of fiduciaries such as "trustworthiness", "fidelity", "loyalty", confidentiality, "good faith", etc. are all primarily moral requirements and evidently constitutive of fiduciary relationships. Hence trustworthiness on the part of the lawyer is not merely an "aspirational" ideal which morally enhances the relationship but is indeed constitutive of it. ${ }^{52}$ A lawyer who in contravention of legal ethics unjustifiably breaches the confidence of his or her client effectively destroys or, at least, seriously impairs the relationship by destroying that trust or faith which the client reposes in him or her. But this only shows that ethical behaviour is a pre-requisite for establishing and maintaining a relationship that is characterised by (mutual) trust. It is especially important that the client is able to have the assurance, to have grounds to believe, to trust that the lawyer will act in her best interests (ethically) in providing the services she seeks from him or her. Only ethical (trustworthy) behaviour or an assurance thereof or will allow such a relationship of trust to exist. This suggests then that such fiduciary relationships are qualified by the aspect of faith or, as Clouser styles it, the "fiduciary aspect" ${ }^{\prime 53}$

It may well be true that the services which the client seeks from the lawyer though concerning legal matters (legal advice, conduct of litigation, preparation of legal documents, etc.) insofar as those services involve the client entrusting those legal-needs-to-be-served to the care of the lawyer, are of an ethically qualified character. The service which the relationship facilitates is that of legal care as it is medical care which the doctor provides to the patient. Acts of caring are ethically qualified actions and within professional relationships they require ethically qualified acts of good faith, fidelity, loyalty, etc. But the relationship itself is characterised by the role of the aspect of faith or trust.

Sydney, 1977). For an up-to-date view of developments in this area of law see C E F Rickett "Equity: Fiduciary Law, Remedies Law and Equitable Compensation" in D Goddard and C E F Rickett Developments in the Law of Obligations (New Zealand Law Society, Wellington 1996) 31-63.

52 Andrew Brien considers this an essential ethical component of all "professional" relationships owing to the inherent vulnerability of the user of professional services who must place their trust in the person providing those services. A Brien "Creating and Maintaining and Ethical Profession" (1994) Chartered Accountants Journal 34, 35.

53 R Clouser The Myth of Religious Neutrality (University of Notre Dame Press, Notre Dame, 1991) 207-208. For institutions and organisations considered by Clouser to be qualified by the aspect of faith see 235-236 and table at 260 . 
In the lawyer-client relationship the lawyer is en-trusted ${ }^{54}$ with the care of the client because of the legal knowledge and skills which she or he possesses and which the client lacks. The client must trust the lawyer to exercise that knowledge and skill in the client's interest. Only by so trusting the lawyer can the latter properly carry out his or her role within the fiduciary relationship. The lawyer for his or her part can only do this by caring for the client's interests, that is, by acting in a trustworthy manner with respect to those interests.

\section{Legal ethics and law}

A lawyer who breaches the fiduciary duty of confidentiality to the client ${ }^{55}$ or violates the duty not to allow his or her interests to conflict with those of the client, ${ }^{56}$ however, has not merely acted unethically, in contravention of legal ethics, but in acting unethically has damaged the interests of the client. From the perspective of Dooyeweerd's legal ontology we have a damaging disruption of the harmony of interests within the fiduciary relationship that calls for the positivising of a jural norm within the inner jural sphere (jural aspect) of the relationship in order to re-harmonise those interests in a jural (retributive) manner. ${ }^{57}$ In other words, what is required is the giving of what is owed to the injured party as a matter of justice. Hence it is not with the intent of enforcing norms of moral conduct qua moral conduct that the (state) common ("private") law of fiduciaries (Equity) regulates such violations of the fiduciary relationship. Rather it is a matter of public justice (but not "public law") that internal jural norms of such relationships should in the public interest be reinforced with the coercive backing of public-legal sanctions.

Absent an issue of inter-relational justice, an ethical failure to positivise the merely aspirational or supererogatory norms in the relationship is not the proper concern of the state to coercively correct. ${ }^{58}$ Thus, in the (ethically qualified?) relationship of friendship not

54 Applying the modal structural analysis this entrusting is a positivisation of the norm of faith within the functioning of the leading faith ("pistic", "fiduciary") aspect of the lawyer-client relationship. However, for that realisation of the faith norm (entrusting) to take place within that relationship requires the ethical norm of love or care in the core sense of "troth" or fidelity, good faith etc., which is, at least in part, constitutive of the relationship, to be positivised in ethically good actions which show the actor to be worthy of trust.

55 Rule 1.08, Rules of Professional Conduct for Barristers and Solicitors (4th ed, New Zealand Law Society, 1996).

5t Rule 1.03, above $n 55$.

57 See above nn $18-22$ and accompanying text.

58 For a similar view on the general issue of state enforcement of morality see D N MacCormick "A Moralistic Case for A-Moralistic Law?" (1985) 20 Val U L Rev 1, who speaks of enforcing "duties of justice", 30-37. For a Dooyeweerdian view, van der Vvyer above n 47, 170-171, disagreeing with Devlin, and also van der Vvyer above n 44, 364-369. 
carrying through into deed the thought of giving your friend a gift as a token of appreciation does not positively harm the relationship, though the failure is a lost opportunity to enhance the relationship and to further strengthen the bonds of friendship. Similarly, in the lawyerclient relationship a lack of generosity towards an impoverished client will not attract legal penalty though the codes of the law profession often contain aspirational ethical ideals. ${ }^{54}$ Such codes however overlap with state law insofar as they contain statements of fiduciary duties the breach of which may result in the disciplinary processes of the profession being invoked.

As a form of self-regulation the rules of professional conduct, ${ }^{61}$ which involve the sanctioning of professional duties, represent a concrete expression of the inner jural sphere of professional legal relationships as a private law of a fiduciary-ethical type so far as the lawyer-client relationship is concerned - fiduciary-ethical because this form of regulation serves the purpose of maintaining the integrity of the lawyer's professional relationship as a relationship based on trust (fiduciary or faith aspect) by attending to its inner jural dimension (retributive harmonising of interests) through the imposition of ethically "opened up" jural norms of behaviour (legal-moral duties). This private form of regulation, however, itself receives public-legal recognition in the Law Practitioners Act 1982 as part of the state's internal communal law (public law) which aims to promote the public interest in having an ethically self-regulating profession. Hence, there is a public-legal requirement for the profession to regulate itself through the promulgation of a code of conduct and the maintenance of internal disciplinary institutions and procedures, just as there are similar requirements for the medical profession. ${ }^{\text {i }}$ The internal jural competence of the private professional body (New Zealand Law Society) to make rules regulating its members' conduct has not been usurped by direct public legal regulation but has been sanctioned by public law.

This public law form of indirect regulation is to be differentiated from the direct form of (state) private law regulation of the private (non-state) inter-individual relationships of lawyer and client or doctor and patient through the law of fiduciaries (and law of tort and contract) in the interests of maintaining justice between the parties to these relationships.

59 The rules of professional conduct in New Zealand and Australia, however, make no reference to service "pro bono publico" nor is there any established pro bono scheme in either country. See Dal Pont Lazuyers' Professional Responsibility in Australia and New Zealand (Law Book Company, Sydney, 1996) $75-76$.

61) On the aspirational versus regulatory model of codes of professional ethics see $C$ Sampford and $C$ Parker "Legal Regulation, Ethical Standard-Setting, and Institutional Design" in Parker and Sampford (eds) Legal Ethics and Legal Practice (Clarendon Press, Oxford, 1995) 11-24, 14-17.

61 Medical Practitioners Act 1995. 
indicate the relevance of the "modal" analysis for the perennial jurisprudential debate over the relationship of law and morality with a particular application to legal ethics.

Which brings us to a third possible objection. Surely the attempt to confine the ethical/moral dimension of experience to a non-jural (non-economic, non-aesthetic, etc) sphere of normativity which excludes principles and norms of justice is a highly artificial exercise and runs counter to the history of legal and ethical philosophy? In the face of this objection I can only point to the necessity which both legal philosophers and legal doctrinalists acknowledge of distinguishing between the normative requirements of legal justice which are internal to the law and non-legal or non-jural normative ethical or moral requirements, such as good faith, which, whilst not necessary constituents of valid law, nevertheless form part of a pervasive and widely-held view of justice that ought to be embodied in the law. Dooyeweerd's notion of the normative jural aspect and the method of modal analysis provides a means of explaining the complexities of these interconnections between distinctive juristic and moral norms and how they can mesh in legal-moral principles or norms such as good faith.

Furthermore, without some such distinction between the jural and ethical (and faith or fiduciary) aspects it becomes almost impossible to clearly explain the connections between law and morality or ethics when considering the topic of legal ethics. The vague and normatively all-encompassing definitions of ethics or morality as to do with "right and wrong" or "good and bad" are completely useless as a basis for explaining such areas of human practice. Similarly the consigning of all issues of normativity involving "justice" or "public policy", "public morality" or "reasonableness" to an autonomous sphere of "values" will not do either. One of the greatest contributions of Dooyeweerd's jurisprudential method is to show, not merely that questions of (legal) value or normativity and issues of (legal) fact, what we lawyers and jurists ambiguously refer to as issues of "law and fact", are inextricably connected, but to explain in a highly sophisticated manner how fact and value are related in the law through his idea of the "law-", or "norm-", "side" of legal phenomena. He could only have arrived at that insight through a fundamental rejection of the prevailing fact-value dichotomy and by adopting a unique "structural" approach. Notwithstanding modern attempts to bridge the fact-value divide I would doubt whether there exists a more sustained, systematic and comprehensive exposition of legal concepts which has been able to relate the deepest and most abstract concerns of legal philosophy to the jurisprudential concerns of legal doctrinalists and practising lawyers in such a comprehensive and all-encompassing manner. Much more than this limited study has been able to accomplish, however, will be required to expound the full complexity of Dooyeweerd's jurisprudence and its implications for doctrinal exposition and legal practice. 